\title{
Ameliorative effects of Moringa olifera on copper nanoparticles induced toxicity in Cyprinus carpio assessed by histology and oxidative stress markers
}

Aasma Noureen ${ }^{1,5}$, Farhat Jabeen*1, Tanveer A. Tabish ${ }^{2}$, Muhammad Kashif Zahoor ${ }^{1}$, Muhammad

$\mathrm{Ali}^{1}$, Rehana Iqbal $^{3}$, Sajid Yaqub ${ }^{1}$, Abdul Shakoor Chaudhry ${ }^{4}$

1. Department of Zoology, Government College University Faisalabad, 38000, Pakistan

2. College of Engineering, Mathematics and Physical Sciences, University of Exeter, Stocker Road, Exeter, EX4 4QF, United Kingdom

3. Department of Zoology, Bahauddin Zakariya University, Multan, 60800, Pakistan

4. School of Natural and Environmental Sciences, Newcastle University, Newcastle upon Tyne, NE1 7RU, United Kingdom

5. Virtual University of Pakistan, Lahore

\begin{abstract}
Nanoparticles (NPs) enter the environment mainly through waste water effluents, accidental spillage, and industrial runoffs. This is worrying because NPs can enter the human body owing to their large aspect-to-size ratio and reactive surfaces that facilitate their penetration through biological barriers and thus can induce oxidative stress in host cells. Therefore, there is a growing concern about the toxicity of NPs which needs to be addressed. Thus, this study investigated the ameliorative effects of Moringa oliefera seed extract (MOSE) in Cyprinus $(C)$ carpio exposed to $\mathrm{Cu}-\mathrm{NPs}$. For the in vivo assessment of shielding effects of MOSE, 240 samples of C. carpio (40$45 \mathrm{~g}$ ) were randomly allocated into 24 experimental tanks (10 fish/tank of 40L) $24 \mathrm{~h}$ prior to the start of this experiment. The experimental fish were challenged to the water-born exposure of a pre-determined dose of $1.5 \mathrm{mg} \mathrm{Cu}-\mathrm{NPs} / \mathrm{l}$ along with pre and post treatment with different doses (100 or 200 or $300 \mathrm{mg} / \mathrm{l}$ ) of MOSE for 28 days. The MOSE showed significant ameliorative effect on the antioxidant defense, in response to the elevated levels of $\mathrm{Cu}$-NPs-induced oxidative stress. It also played a protective role as indicated by the suppression of histological alterations in gills and liver of fish exposed to $\mathrm{Cu}-\mathrm{NPs}$. It is concluded that $\mathrm{Cu}-\mathrm{NPs}$ induced toxicity in C. carpio was ameliorated by the use of MOSE in this study. Moreover, post-CuNPs treatment stage showed more protective effects of MOSE than the pre-CuNP treatment phase. Further studies are suggested to determine the optimum dose and delivery method of MOSE for similar or different NP exposed fish.
\end{abstract}

Key words: Fish, CuO-NP, toxicity, Moringa olifera, stress enzymes, histology

Introduction 
Copper nanoparticles ( $\mathrm{Cu}$-NPs) have recently gained significant attention in nanomedicine as a contrast agent in novel drug delivery systems as well as for the diagnosis of diseases. The antiinflammatory, anti-microbial and anti-fungal activities of $\mathrm{Cu}-\mathrm{NPs}$ have made them an ideal candidate for use in anti-infective medical devices, plastics, coatings and textiles [2-3]. The widespread use of $\mathrm{Cu}-\mathrm{NPs}$ has raised concerns on their biosafety profile owing to their potential adverse impacts on different ecosystems [4]. Cu-NPs have also been used as a disinfectant for wastewater treatment because of their resistive role against microbes in wastewater [5-6]. Similar to other NPs, $\mathrm{Cu}-\mathrm{NPs}$ can cross the biological barrier such as plasma membrane, which in turn can induce oxidative stress [7]. Moreover, $\mathrm{Cu}-\mathrm{NPs}$ can be accumulated in liver and gills tissues of fish [8]. Nanoparticles (NPs) have very small size which facilitates their easy crossings through biological barriers (membranes), which might interrupt the normal structure and function of various organ systems [9-11]. Also, NPs have the ability to facilitate the direct generation of harmful reactive oxygen species (ROS) inside the cells [4; 12-14]. These oxygen centered species may produce injury inside the cell including DNA damage and lipid peroxidation. The widespread use of NPs poses unknown threats to the environmental quality and human health by increasing the chance of exposures [4]. The interactions of these NPs with other metals and organic pollutants have also enhanced the toxicity and bioaccumulation of both NPs and other micro-pollutants [1516]. The aquatic species are especially at risk as a result of NPs exposures. This is most likely because the ultimate sink for the accumulation of all micro-pollutants and NPs is water. There is an emerging concern about the chemical behavior of NPs in aquatic systems and their accumulation and toxicity in aquatic organisms [17-18]. Therefore, it is important to study the bioaccumulation and toxicity of $\mathrm{Cu}-\mathrm{NPs}$ in living organisms to evaluate their fate and management in environmental and biomedical application to solve real-world problems. For this purpose, selected fish specimens were used as a potential bio-indicator of aquatic pollution because of their sensitivity to frequently changing ecosystems.

Various plant secondary metabolites are known for their antioxidant properties and so these can be used as protecting agents against toxins [19-20]. Moreover, herbs and medicinal plants are promising to be an important source of therapeutics in fish [21-22]. Plants have antioxidant properties because of the presence of active phytochemicals including vitamins, flavonoids, terpenoids, carotenoids, cumarins, curcumins, lignin, saponin, and plant sterols etc. [19-21]. The World Health Organization (WHO) encourages the use of medicinal herbs and plants to minimize the toxic effects of such contaminants. It is well-known that more than $80 \%$ of the world's population rely on traditional medicine for their primary healthcare needs to avoid the side effects and expenses of synthetic medications. Hence, these living factories are able to generate endless biochemical compounds [22]. These naturally occurring phytochemical compounds exhibit antimutagenic and anti-carcinogenic properties and play a valuable role to prevent certain types of diseases including cancer by mitigating the toxic effects of chemicals as evident from epidemiological and experimental studies. Many attempts were made to use the natural materials as feed additives to enhance efficiency of feed utilization and animal performance [23].

Moringa oleifera plant (M. oleifera) belongs to the sub-Himalayan areas of India, Pakistan, Bangladesh and Afghanistan, where various components of these plants are used in general medicine [24-28]. This plant is known as "Suanjna" in Pakistan and its inflorescence is used as a vegetable while pods are used for pickles. It has considerable economic importance because of its several nutritional, pharmacological [29] and industrial applications [30]. M. oleifera contains 
natural antioxidants such as vitamin C, tocopherols, flavonoids and other phenolic compounds [26; 31-33].

To the best of our knowledge, no previous studies are available on the use of Moringa oleifera seed extracts to combat $\mathrm{Cu}-\mathrm{NPs}$-induced toxicity in C. carpio. C. carpio was selected because of its tolerant nature and potency of adaptability in different habitats. Therefore, the seed extract of Moringa olifera, which is indigenous to Pakistan, was used in this study to investigate its antioxidant potential against $\mathrm{Cu}-\mathrm{NPs}$ induced toxicity in $C$. carpio.

\section{Materials and Methods}

The in vivo experiments with fish were carried out after the approval of the Animal Ethics Committee, Government College University, Faisalabad (GCUF) Pakistan. The experimental fish received proper care and husbandry in compliance with the Animal Ethics Committee guidelines and the minimum possible number of fish was used in this experiment.

\section{Fish maintenance and treatment plan}

Two hundred forty samples of $C$. carpio (initial live-weight of 40-45g) were procured from the Fish Seed Hatchery Satiana Road in Faisalabad, Pakistan. These fish were randomly distributed into 24 experimental tanks (10 fish/ tank of capacity 40L) around $24 \mathrm{~h}$ prior to the experiment. The fish were acclimatized to the tanks and feeds for a fortnight. The fish were then daily fed with commercial carp food containing 65\% crude protein and 10\% fat (manufacture by Wudi Taijia Agriculture Development Co., Limited China). Each glass tank had recirculating filtered water where the fish were kept under normal photoperiod (12 hrs light: $12 \mathrm{hrs}$ dark) and temperature (26 $\left.{ }^{\circ} \mathrm{C}\right)$.

The engineered Cu-NPs of 60-80 nm (Cat. No. 7440-50-8) were purchased from Sigma Aldrich Ltd, USA. The fresh stock solution of Cu-NPs was prepared in ultra-pure water (Millipore, 18.2 $\mathrm{Mcm}$ resistance and sonicated for 5-6 h to increase the dispersion of $\mathrm{Cu}-\mathrm{NPs}$. No coating or surfactant was used in the study to avoid any added potential toxicity that may be triggered by such a coating /surfactant. The water was changed daily during the experiment and the $\mathrm{Cu}-\mathrm{NPs}$ uptake was facilitated through the fresh dosing of $\mathrm{Cu}-\mathrm{NPs}$ after each water change. As the $\mathrm{Cu}$ NPs were purchased from Sigma Aldrich Ltd, the accompanied data sheets were used to obtain initial physiochemical properties of these NPs. Moreover, the $\mathrm{Cu}-\mathrm{NPs}$ used in the study were characterized by using X-ray diffraction (XRD), scanning electron microscopy (SEM) and transmission electron microscopy (TEM) as reported in our previous study [34]). The XRD technique characterized the primary average crystallite size of $\mathrm{Cu}-\mathrm{NPs}$ in the range of $78.33 \mathrm{~nm}$. In addition the SEM method revealed the homogeneous dispersion of particles that were found to be within the range of $65-90 \mathrm{~nm}$. Conversely, the TEM method revealed the individual particle size of 70-90 nm where most particles had irregular morphology and cubical crystalline form [34]. Dried seeds of Moringa olifera were purchased from a local authenticated scientific store. Their taxonomic status was confirmed from the Department of Botany at GCUF. The seeds were pulverized into fine powder using a grinder (Renker, Model: GMO 1 grinder), sieved to remove coarse particles and stored in an airtight container. Moringa olifera seed extract (MOSE) was prepared by using the method of Khan et al. [35] with some modifications by mixing about $500 \mathrm{~g}$ of finely ground Moringa olifera seeds with methanol and the mixture was then kept at room temperature for 7 days. The suspension was filtered through Whatman No. 1 filter paper and the 
liquid extract was dried at room temperature. A fresh stock solution of MOSE for the treatment was prepared daily to reduce the effects of ageing on the stock solutions. The required quantity of MOSE was added in ultra-pure water which was shaken (Shaker SK 0330-pro) and mixed thoroughly at $200 \mathrm{rpm}$ for $1 \mathrm{hr}$ to enable the total dispersal of suspension.

As shown in Table 1, the experimental fish were exposed to either negative control receiving $0 \mathrm{mg}$ $\mathrm{Cu}-\mathrm{NPs}$ or MOSE /l, positive control receiving only $1.5 \mathrm{mg} \mathrm{Cu}-\mathrm{NPs} / 1$ or 100 or 200 or $300 \mathrm{mg} / \mathrm{l}$ of MOSE pre and post treatment with $1.5 \mathrm{mg} \mathrm{Cu}-\mathrm{NPs} / 1$ for 28 days for the assessment of ameliorative effects of MOSE against $\mathrm{Cu}-\mathrm{NPs}$ induced toxicity under a semi-static water flow condition. About $80 \%$ water in each tank was replaced with fresh water every day before fresh dosing, where needed, with CuNPs and MOSE as described above. This fixed dose of $1.5 \mathrm{mg} \mathrm{Cu}-$ NPS was selected as a sub-acute dose from our previous study where the fish were treated with the increasing doses of 0 to $1.5 \mathrm{mg} \mathrm{Cu}-\mathrm{NPs} / 1$ [34]. In the pre- treatment phase, the fish were pretreated first with MOSE and then three hrs after with $1.5 \mathrm{mg} \mathrm{Cu}-\mathrm{NPs} / 1$. Conversely for the posttreatment phase, the experimental fish were exposed first to $1.5 \mathrm{mg} \mathrm{Cu}-\mathrm{NPs} / 1$ and then three hrs after to MOSE. The doses of MOSE were based on the LC50 of MOSE and Cu-NPs for C. carpio.

After the completion of exposure, the fish were humanely killed, washed and dissected to extract tissues (gills and liver) which were then processed for the analysis of histology and oxidative stress as indicated by different enzyme concentrations.

Table 1 Description of various treatments that were applied to tanks containing different groups of fish (C. carpio)

\begin{tabular}{llll}
\hline Sr. No. & Groups & \multicolumn{2}{c}{ Treatment Phases } \\
\cline { 3 - 4 } & & Pre-treatment & Post-treatment \\
\hline 1 & Negative Control & & \\
& (without any treatment) & & \\
2 & Positive Control & & \\
& $(1.5 \mathrm{mg} \mathrm{Cu}$-NPs $/ 1)$ & $100 \mathrm{mg} \mathrm{MOSE} / 1+$ & $1.5 \mathrm{mg} \mathrm{Cu}-\mathrm{NPs} / 1+100 \mathrm{mg}$ \\
& CuNM1 & $1.5 \mathrm{mg} \mathrm{Cu}-\mathrm{NPs} / 1$ & $\mathrm{MOSE} / 1$ \\
& & $200 \mathrm{mg} \mathrm{MOSE} / 1+$ & $1.5 \mathrm{mg} \mathrm{Cu}-\mathrm{NPs} / 1+200 \mathrm{mg}$ \\
5 & CuNM2 & $1.5 \mathrm{mg} \mathrm{Cu}-\mathrm{NPs} / 1$ & $\mathrm{MOSE} / 1$ \\
& & $300 \mathrm{mg} \mathrm{MOSE} / 1+$ & $1.5 \mathrm{mg} \mathrm{Cu}-\mathrm{NPs} / 1+300 \mathrm{mg}$ \\
\hline
\end{tabular}

M1, M2 and M3 represent different doses of MOSE

Body Weight and Body Length of Experimental Fish

Each fish was weighed and measured at the start and the end of this experiment.

Sample Collection and Processing

The tissues (gills and liver) of all treated fish were collected at the start and the end of 28 days for the assessment of oxidative stress and histological changes. The tissues for oxidative stress were immediately processed for the estimation of lipid peroxidation, glutathione and catalase. The 
tissues for the histological assessment were immediately immersed in fixative sera as described later.

Assessment of oxidative stress enzymes

The homogenates of gills and liver tissues were prepared by mixing $1 \mathrm{~g}$ of tissue and $0.1 \mathrm{M}$ phosphate buffer in a homogenizer (Potter-Elvejham), separately. Each suspension was centrifuged to collect the supernatant which was stored in freezer at $-20{ }^{\circ} \mathrm{C}$ [36]. The lipid peroxidation (LPO) was measured by the method of Ohkawa et al. [37]. Briefly, about $0.2 \mathrm{ml}$ tissue homogenate was mixed with $0.2 \mathrm{ml}$ SDS (8.1\%), $1.5 \mathrm{ml}$ acetic acid (20\%) and $1.5 \mathrm{ml}$ aqueous thiobarbutaric acid $(0.8 \%)$. The mixture was heated at $95^{\circ} \mathrm{C}$ ( 1 hour) in a water bath. After that a mixture was prepared by adding $1 \mathrm{ml}$ distilled water and $5 \mathrm{ml}$ of $\mathrm{n}$-butanol and pyridine (15:1) solution which were then shaken vigorously on a vortex (Super mixer. MC-05). The contents were centrifuged to collect supernatants which were checked for absorbance at $532 \mathrm{~nm}$. Tetramethoxypropane was used as an external standard. For the Catalase (CAT) testing, about 50 $\mu \mathrm{l}$ of tissue homogenate was thoroughly mixed with $1.95 \mathrm{ml}$ of $50 \mathrm{mM}$ phosphate buffer in a cuvette. The changes in absorbance were then recorded after adding $1 \mathrm{ml}$ of $30 \mathrm{mM} \mathrm{H}_{2} \mathrm{O}_{2}$ at 240 $\mathrm{nm}$ at $30 \mathrm{sec}$ intervals [38]. The levels of Glutathione (GSH) in the liver and gills tissues homogenates were measured at $412 \mathrm{~nm}$ by using the method of Sedalk and Lindsay [39]. For this purpose each homogenate was mixed with 50\% trichloroacetic acid and the each tube containing the mixture were centrifuged at $1000 \mathrm{rpm}$ for $5 \mathrm{~min}$. About $0.5 \mathrm{ml}$ of supernatant were mixed with $2.0 \mathrm{ml}$ of Tris-EDTA buffer and $0.1 \mathrm{ml}$ of $0.01 \mathrm{M} 5$ ' 5' - dithio-bis-2-nitrobenzoic acid. The mixture was kept at room temperature for 5 minutes before the absorbance was recorded at $412 \mathrm{~nm}$ by a spectrophotometer (U-2800 Hitachi (200-1100).

Assessment of histological alterations

The fresh pieces of tissues (gills and liver) were fixed in sera containing $50 \mathrm{ml}$ absolute alcohol, $40 \mathrm{ml}$ formaldehyde, and $10 \mathrm{ml}$ glacial acetic acid for 5-6 hours. After fixation, the tissues were dehydrated using different ascending grades of ethanol (70-100\%). After dehydration, the samples were kept in cedar wood oil and banzol. Then the samples were embedded in paraffin blocks before tissue sectioning. The tissue sections of about $4 \mu \mathrm{m}$ were cut by a microtome (SLEE Rotary Microtome CUT5062 by Nikon Instruments Europe) before their staining in the haematoxylineosin (HE) mixture as described by Bancroft and Stevens [26]. The stained sections from the control and treated specimens were observed and photographed by using an optical microscope (Nikon E200 POL) that was connected with a digital camera for histological examination [40]. The quantification of histological changes was done by using a five graded examination scheme: (-) no histological alterations (normal histological structure); (+/-) mild histological alterations; (+) moderate histological alterations; $(++)$ severe histological alterations; $(+++)$ very severe histological alterations.

Statistical Analysis

The data were analysed by Minitab17 software using General Liner Model (ANOVA) and SPSS Statistics 21.0 using ANOVA and the Tuckey's post-hoc test was used to compare means. The differences between means were declared significant if $\mathrm{P}<0.05$.

Results 


\section{Weight and length measurements of experimental Fish}

Table 2 shows the significant differences $(\mathrm{P}<0.05)$ between treatment means for the weight and length of $C$. carpio at the start and the end of experiment. The positive control which was treated with $1.5 \mathrm{mg} \mathrm{Cu}-\mathrm{NPs} / \mathrm{l}$ showed decrease in weight and length after 28 days while negative control (not treated with $\mathrm{Cu}-\mathrm{NPs} / \mathrm{MOSE}$ ) and all other treatment groups which were pre and post-treated with MOSE after their exposure to $1.5 \mathrm{mg} \mathrm{Cu}-\mathrm{NPs} / 1$ showed increase in weight and length measurements. The increases in weight and length were found in a dose dependent manner where both the weight and length of $C$. carpio increased with the increasing doses of MOSE. It was also observed that the post-treatment of MOSE showed more ameliorative effects as compared to the pre-treatment.

\section{Assessment of oxidative stress enzymes}

Table 3 revealed the concentration of oxidative stress enzymes (LPO, GSH and CAT) in the liver and gills of $C$. carpio among different treatment groups. Overall it was observed that MOSE significantly $(\mathrm{P}<0.050)$ protected the $\mathrm{Cu}-\mathrm{NPs}$ treated fish. The post-treatment of MOSE showed more mitigating effects than the pre-treatment of MOSE. Moreover, the protective effects of MOSE were in a dose-dependent manner with the increase in the dose of this plant extract. 
Table 2: Mean \pm SE of weight and length of $C$. carpio treated with different concentrations of MOSE before and after the exposure to 0 or $1.5 \mathrm{mg} \mathrm{Cu}-\mathrm{NPs}$ for 28 days among different treatment groups.

\begin{tabular}{|c|c|c|c|c|c|c|c|c|}
\hline \multirow{2}{*}{ Parameters } & \multicolumn{8}{|c|}{ Groups } \\
\hline & $\mathrm{C}$ & $\mathrm{CuN}$ & Pre-CuNM1 & Pre-CuNM2 & Pre-CuNM3 & Post-CuNM1 & Post-CuNM2 & Post-CuNM3 \\
\hline Initial Weight (g) & $45.20 \pm 0.45$ & $45.28 \pm 0.34$ & $45.59 \pm 0.47$ & $45.66 \pm 0.63$ & $45.40 \pm 0.65$ & $45.35 \pm 0.24$ & $45.43 \pm 0.26$ & $45.40 \pm 0.23$ \\
\hline Initial Length $(\mathrm{cm})$ & $14.57 \pm 0.32$ & $14.40 \pm 0.56$ & $14.90 \pm 0.20$ & $14.50 \pm 0.95$ & $14.33 \pm 1.10$ & $14.23 \pm 0.11$ & $14.30 \pm 0.13$ & $14.28 \pm 0.15$ \\
\hline Final Length $(\mathrm{cm})$ & $18.04 \pm 0.46^{\mathrm{a}}$ & $13.57 \pm 0.67^{\mathrm{e}}$ & $16.00 \pm 0.53^{\mathrm{c}}$ & $15.40 \pm 0.95^{\mathrm{d}}$ & $17.43 \pm 1.05^{\mathrm{a}}$ & $17.00 \pm 0.5^{b}$ & $17.74 \pm 0.85^{\mathrm{a}}$ & $17.43 \pm 1.08^{\mathrm{a}}$ \\
\hline
\end{tabular}

$\mathrm{N}=$ Nanoparticles; $\mathrm{C}=$ negative control= without added MOSE or $\mathrm{Cu}-\mathrm{NPs} ; \mathrm{CuN} 1.5 \mathrm{mg} \mathrm{Cu}-\mathrm{NP} / \mathrm{l}$ (positive Control); M= MOSE;

M1, M2 and M3 represent different doses of MOSE; means carrying same or no superscripts in the same row did not differ significantly $(P>0.05)$ 
Table: 3 Mean $( \pm$ SE) concentration of LPO, GSH and CAT in liver and gill tissues of $C$. carpio treated with $1.5 \mathrm{mg} / \mathrm{kg}$ of Cu-NPs along with pre and post-treatment of MOSE.

\begin{tabular}{ccccccc}
\hline & \multicolumn{2}{c}{ LPO } & \multicolumn{2}{c}{ GSH } & CAT \\
\cline { 2 - 6 } Groups & Liver & Gills & Liver & Gills & Liver & Gills \\
\hline C & $326.10 \pm 5.66^{\mathrm{E}}$ & $312.2 \pm 3.44^{\mathrm{E}}$ & $1245 \pm 8.65^{\mathrm{E}}$ & $2206 \pm 8.95^{\mathrm{E}}$ & $2.4 \pm 0.01^{\mathrm{A}}$ & $2.50 \pm 0.02^{\mathrm{A}}$ \\
CuN & $546.8 \pm 19.01^{\mathrm{A}}$ & $761.4 \pm 21.05^{\mathrm{A}}$ & $2042 \pm 33.04^{\mathrm{A}}$ & $8007 \pm 50.11^{\mathrm{A}}$ & $2.1 \pm 0.19^{\mathrm{E}}$ & $1.4 \pm 0.05^{\mathrm{D}}$ \\
Pre-CuNM1 & $367.4 \pm 18.03^{\mathrm{B}}$ & $341.5 \pm 14.04^{\mathrm{B}}$ & $1344 \pm 26.05^{\mathrm{B}}$ & $2243 \pm 31.23^{\mathrm{B}}$ & $2.4 \pm 0.13^{\mathrm{D}}$ & $2.7 \pm 0.61^{\mathrm{C}}$ \\
Pre-CuNM2 & $364.5 \pm 13.09^{\mathrm{C}}$ & $335.2 \pm 17.03^{\mathrm{C}}$ & $1340 \pm 22.07^{\mathrm{C}}$ & $2237 \pm 33.51^{\mathrm{C}}$ & $2.5 \pm 0.11^{\mathrm{C}}$ & $2.8 \pm 0.51^{\mathrm{B}}$ \\
Pre-CuNM3 & $361.5 \pm 14.07^{\mathrm{D}}$ & $324.9 \pm 18.07^{\mathrm{D}}$ & $1336 \pm 27.08^{\mathrm{D}}$ & $2219 \pm 32.01^{\mathrm{D}}$ & $2.5 \pm 0.09^{\mathrm{B}}$ & $2.8 \pm 0.48^{\mathrm{B}}$ \\
Post-CuNM1 & $361.4 \pm 17.03^{\mathrm{B}}$ & $338.5 \pm 12.03^{\mathrm{B}}$ & $1541 \pm 24.03^{\mathrm{B}}$ & $2113 \pm 34.13^{\mathrm{B}}$ & $2.6 \pm 0.12^{\mathrm{D}}$ & $2.9 \pm 0.64^{\mathrm{C}}$ \\
Post-CuNM2 & $358.4 \pm 12.09^{\mathrm{C}}$ & $332.2 \pm 14.03^{\mathrm{C}}$ & $1120 \pm 12.03^{\mathrm{C}}$ & $1931 \pm 23.21^{\mathrm{C}}$ & $2.7 \pm 0.01^{\mathrm{C}}$ & $2.9 \pm 0.65^{\mathrm{B}}$ \\
Post-CuNM3 & $356.5 \pm 11.07^{\mathrm{D}}$ & $314.9 \pm 15.04^{\mathrm{D}}$ & $1026 \pm 21.04^{\mathrm{D}}$ & $1714 \pm 12.02^{\mathrm{D}}$ & $2.7 \pm 0.02^{\mathrm{B}}$ & $2.9 \pm 0.71^{\mathrm{B}}$ \\
\hline
\end{tabular}

$\mathrm{N}=$ Nanoparticles; $\mathrm{C}=$ negative control= without added MOSE or Cu-NPs; $\mathrm{CuN} 1.5 \mathrm{mg} \mathrm{Cu}-\mathrm{NP} / 1$ (positive Control); M= MOSE $M 1, M 2$ and M3 represent different doses of MOSE; means carrying same or no superscripts in the same column did not differ significantly $(P>0.05)$ 


\section{Histological observations}

Figure 1 showed the normal histological structure of gills of fish which were not treated with $\mathrm{Cu}$ NPs or plant extract while figure 2 presented the negative control which was treated with $1.5 \mathrm{mg}$ $\mathrm{Cu}-\mathrm{NPs} / \mathrm{l}$ and showing the histological alteration in the gills of $C$. carpio, including Epithelial degeneration (upward arrows $\mathbf{\uparrow}$ ), Lamellar fusion (down word arrows $\downarrow$ ), Lamellar hemorrhage (\) and Lamellar necrosis( $\star$ ). The figures 3-8 showing the pre and post-treatment with MOSE, alongwith $1.5 \mathrm{mg} \mathrm{Cu}-\mathrm{NPs} / \mathrm{l}$. Histological abnormalities were observed but at low extant and the more protective effects were observed in the post treatment with MOSE. The MOSE significantly suppressed histological abrasions in dose dependent manner after 28 days. The severity and intensity of histological alterations are presented in Table 4.

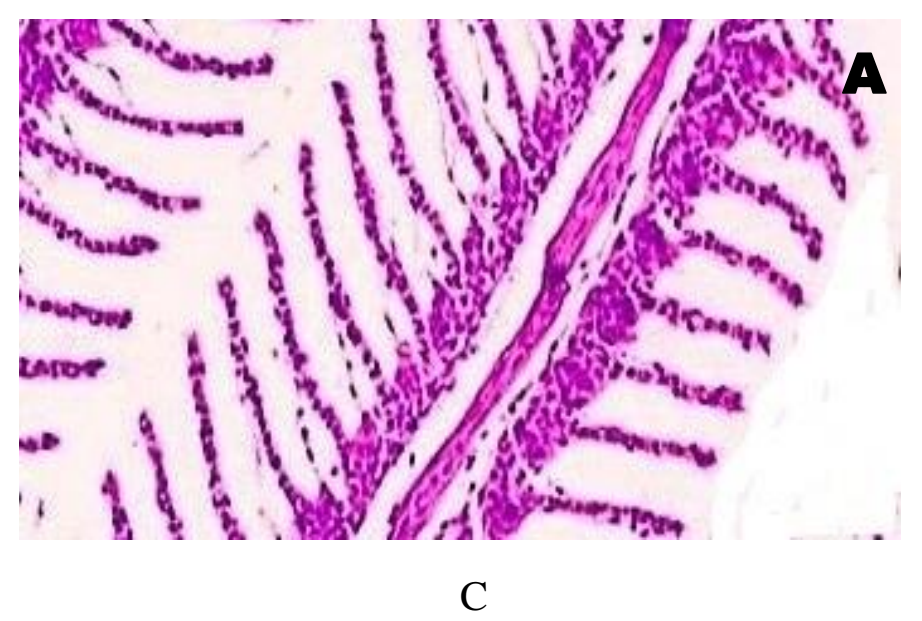

Figure 1 (H\&E; X400): Illustration of the normal histology involving normal structure of gill lamellae and epithelium of gills which were not treated with either MOSE or Cu-NPs. 


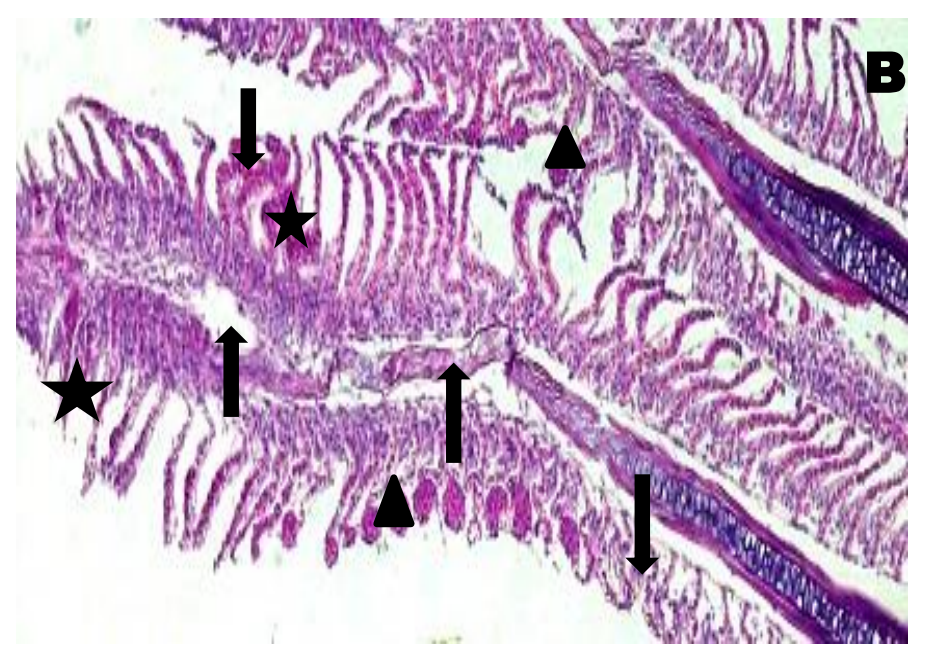

\section{$\mathrm{CuN}$}

Figure 2 showing the negative control which was treated with only $1.5 \mathrm{mg} \mathrm{Cu}-\mathrm{NPs} / \mathrm{l}$. Severe histological alterations were observed including Epithelial degeneration (upward arrows $\boldsymbol{\uparrow}$ ), Lamellar fusion (down word arrows $\downarrow$ ), Lamellar hemorrhage ( $\Delta$ ) and Lamellar necrosis (ㄱ).

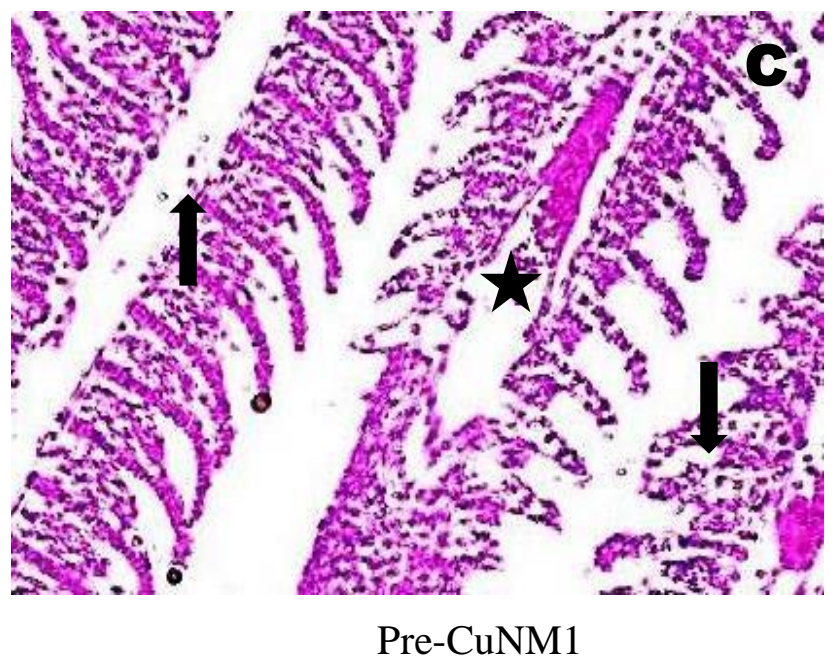

Figure 3 showing the pre-CuNM1 group which was pre-treated with 100mg MOSE / then exposed to $1.5 \mathrm{mg} \mathrm{Cu}-\mathrm{NPs} / \mathrm{l}$ of. Histological abnormalities including Epithelial degeneration (upward arrows $\boldsymbol{\uparrow}$ ), Lamellar fusion (down word arrows $\downarrow$ ) and Lamellar necrosis ( $\star$ ). 


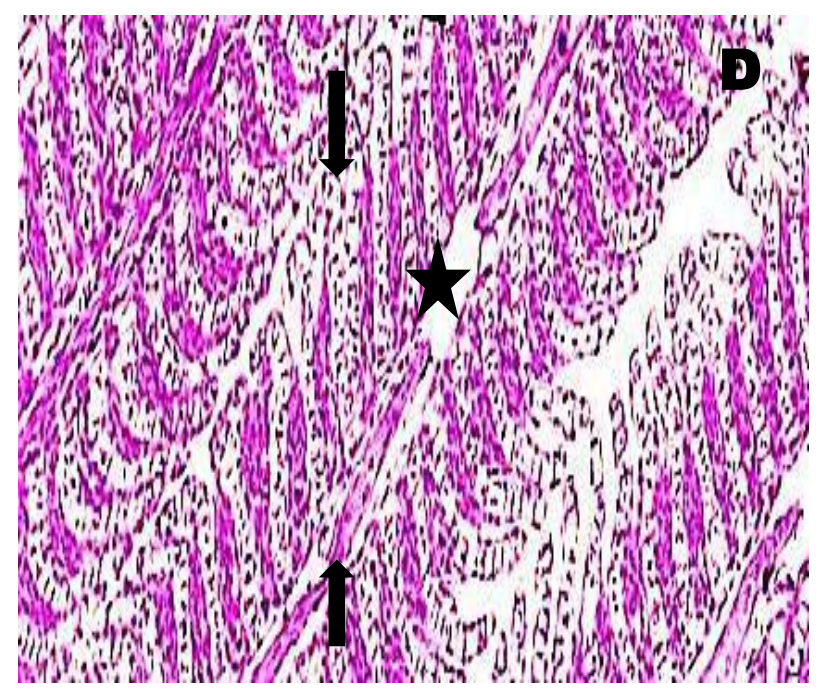

Pre-CuNM2

Figure 4 showing the pre-CuNM2 group which was pre-treated with $200 \mathrm{mg}$ MOSE / then exposed to $1.5 \mathrm{mg} \mathrm{Cu}-\mathrm{NPs} / \mathrm{l}$ of. Histological abnormalities including Epithelial degeneration (upward arrows $\mathbf{1}$ ), Lamellar fusion (down word arrows $\downarrow$ ) and Lamellar necrosis ( $\)$.

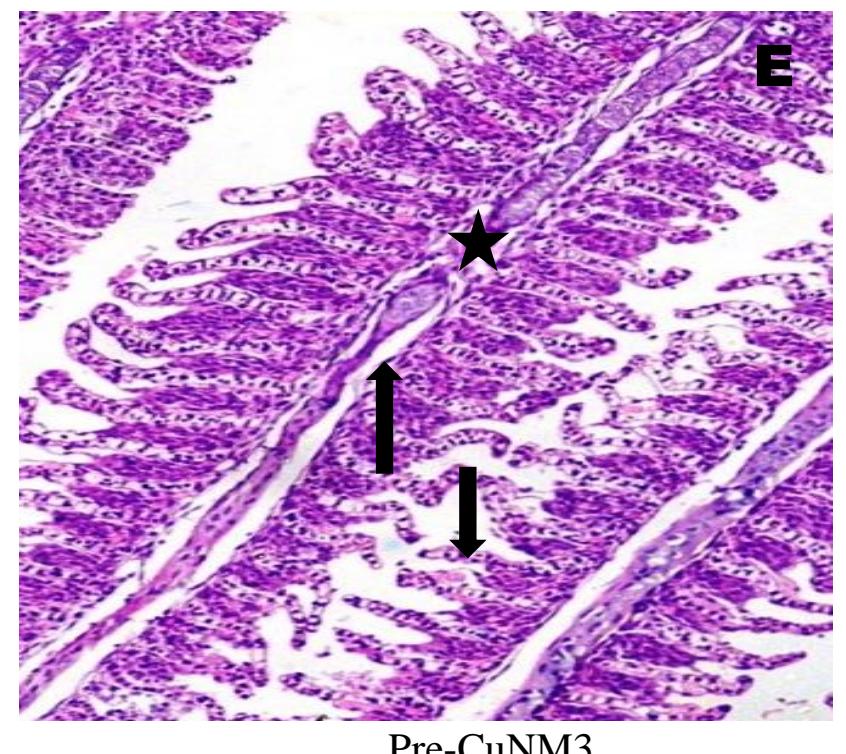

Figur5 showing the pre-CuNM3 group which was pre-treated with $300 \mathrm{mg}$ MOSE / then exposed to $1.5 \mathrm{mg} \mathrm{Cu}-\mathrm{NPs} / \mathrm{l}$ of. Histological abnormalities including Epithelial degeneration (upward arrow \), Lamellar fusion (down word arrows $\downarrow$ ) and Lamellar necrosis $(\not)$. 


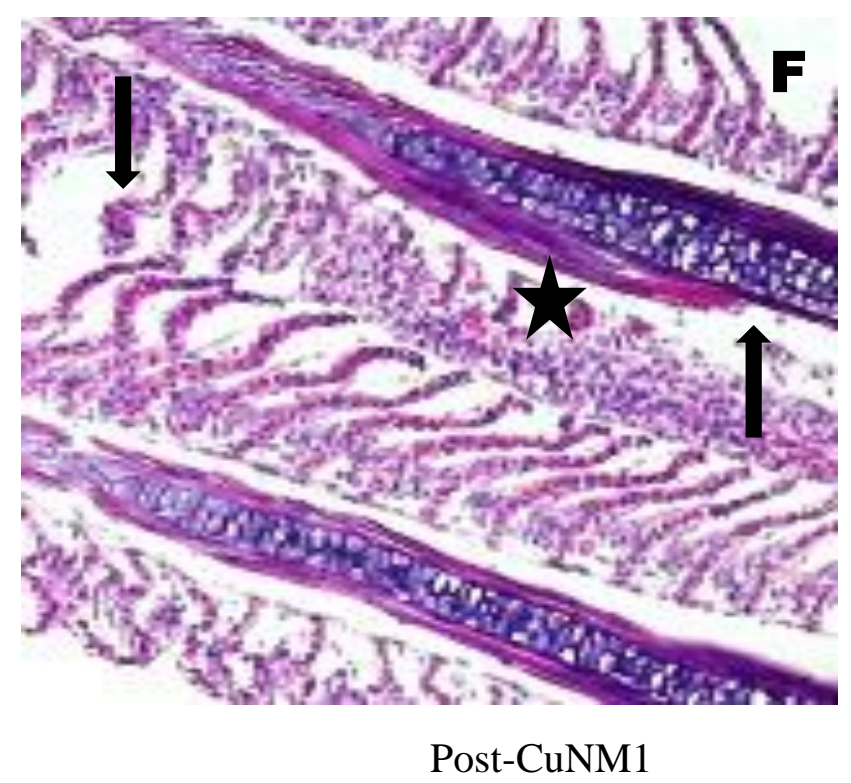

Figur6 showing the post-CuNM1 group which was post-treated with $100 \mathrm{mg}$ MOSE / after exposing to $1.5 \mathrm{mg} \mathrm{Cu}-\mathrm{NPs} / \mathrm{l}$ of. Histological abnormalities including Epithelial degeneration (upward arrows $\mathbf{1}$ ), Lamellar fusion (down word arrows $\boldsymbol{\downarrow}$ ) and Lamellar necrosis (⿻大从 ).

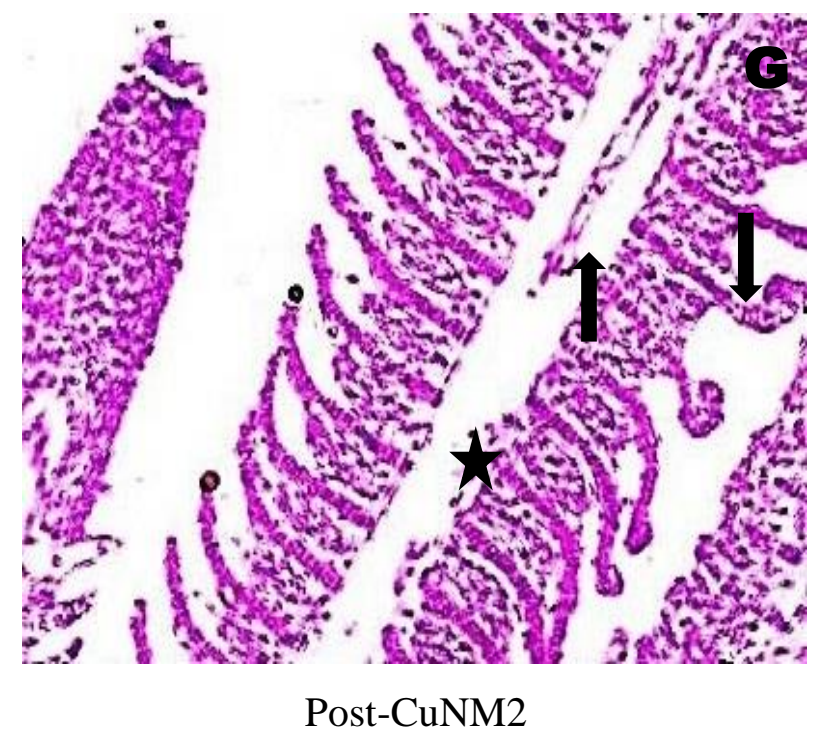

Figur7 showing the post-CuNM2 group which was post-treated with $200 \mathrm{mg}$ MOSE / after exposing to $1.5 \mathrm{mg} \mathrm{Cu}-\mathrm{NPs} / \mathrm{l}$ of. Histological abnormalities including Epithelial degeneration (upward arrows $\mathbf{1}$ ), Lamellar fusion (down word arrows $\boldsymbol{\eta}$ ) and Lamellar necrosis ( $\downarrow$ ). 


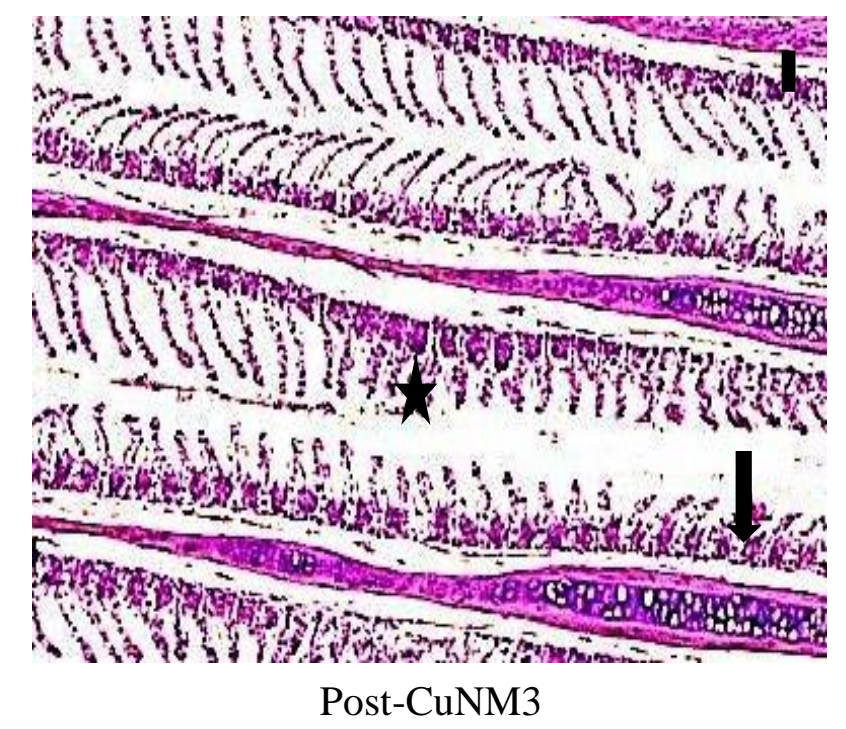

Figur8 showing the post-CuNM3 group which was post-treated with $300 \mathrm{mg}$ MOSE / after exposing to $1.5 \mathrm{mg} \mathrm{Cu}-\mathrm{NPs} / \mathrm{l}$ of. Histological abnormalities including Epithelial degeneration (upward arrows $\mathbf{T}$ ), Lamellar fusion (down word arrows $\boldsymbol{\downarrow}$ ) and Lamellar $\operatorname{necrosis}(\star$ ). 
Table: 4 Histological alterations in gills of $C$. carpio exposed to different concentrations of $M$. olifera along with $1.5 \mathrm{mg}$ Cu-NPs $/$ l.

\begin{tabular}{|c|c|c|c|c|c|c|c|c|}
\hline Histological Alterations & $\mathrm{C}$ & $\mathrm{CuN}$ & Pre-CuNM1 & Pre-CuNM2 & Pre-CuNM3 & Post-CuNM1 & Post-CuNM2 & Post-CuNM3 \\
\hline Epithelial degeneration & - & +++ & ++ & + & $-/+$ & ++ & + & $-/+$ \\
\hline Lamellar fusion & - & +++ & ++ & + & $-/+$ & ++ & + & $-/+$ \\
\hline Lamellar hemorrhage & - & +++ & ++ & + & - & ++ & - & - \\
\hline Lamellar necrosis & - & +++ & ++ & + & $-/+$ & ++ & + & $-/+$ \\
\hline
\end{tabular}

(-) - no histological alterations (normal histological structure); (+/-) - mild histological alterations; (+) - moderate histological alterations; (++) severe histological alterations; $(+++)$ - very severe histological alterations in the gill surface architecture. 
Figure 9 showed the normal liver histology of $C$. carpio in control group which was not treated with $\mathrm{Cu}-\mathrm{NPs}$ or MOSE. The negative control was presented in figure 10 which shows severe histological abrasions including hepatocytes necrosis (black arrow), a-nucleated hepatocytes (green arrow), hepatocytes shrinkage (yellow arrow) and complete degeneration of hematopoietic tissues (red arrow). Histological alterations in the liver of $C$. carpio pre or post- MOSE treatment alongwith $1.5 \mathrm{mg} \mathrm{Cu}-\mathrm{NPs} / \mathrm{l}$ are represented in figure 11-16. It was clearly indicated that Cu-NPs induced alterations in the liver of $C$. carpio and the MOSE significantly suppressed histological abrasions in dose dependent manner after 28 days. The quantitative data for the severity and intensity of histological alterations are presented in Table 4.

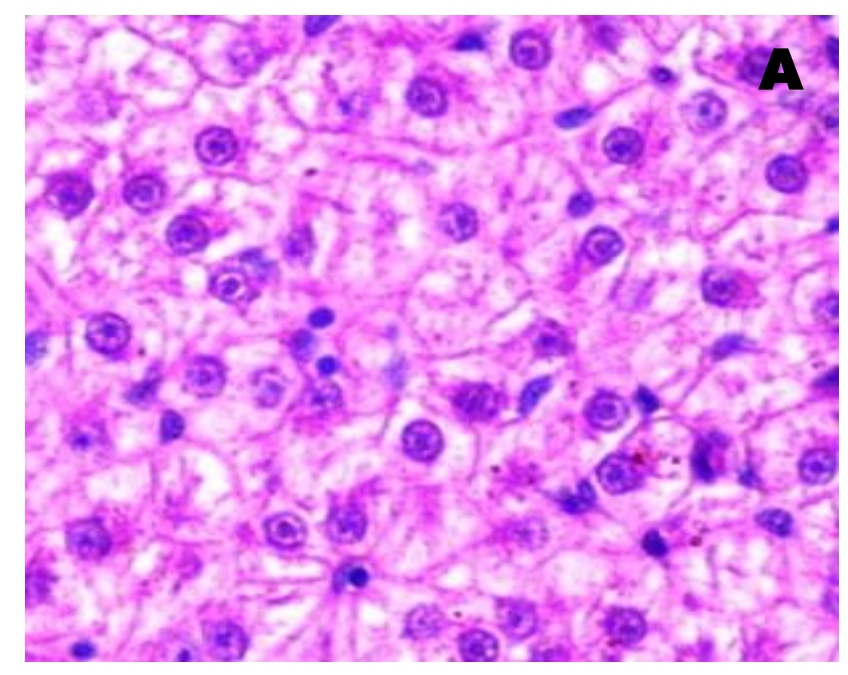

$\mathrm{C}$

Figure 9 (H\&E; X400) showing the normal histology of liver hepatocytes which were collected from fish that were not treated with MOSE or Cu-NPs. 


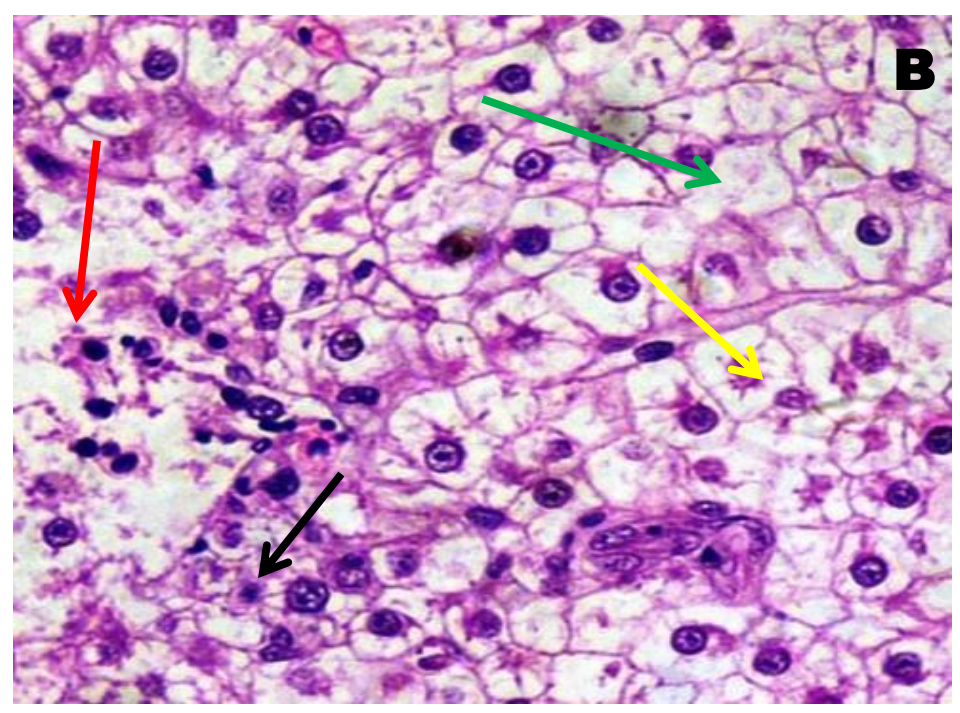

Pre-CuNM1

Figure 10 showing the negative control of liver which was treated with $1.5 \mathrm{mg} \mathrm{Cu}-\mathrm{NPs} / \mathrm{l}$ of . Severe histological abrasions in liver can be seen including hepatocytes necrosis (the black arrow), a-nucleated hepatocytes (green arrow), hepatocytes shrinkage (yellow arrow) and complete degeneration of hematopoietic tissues (red arrow).

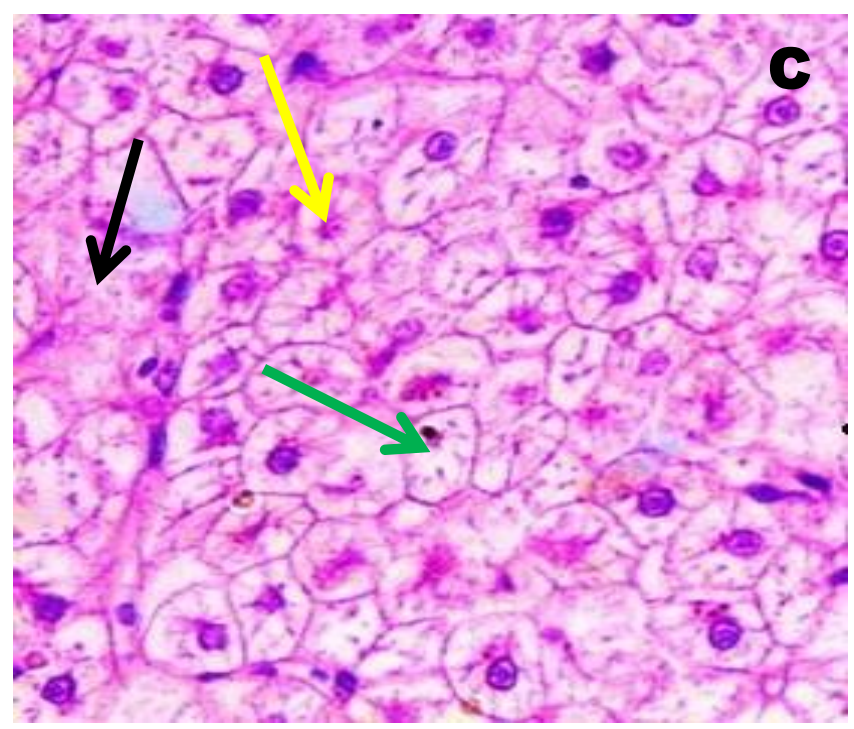

Pre-CuNM1

Figure 11 showing the pre-CuNM1 group which was pre-treated with $100 \mathrm{mg}$ MOSE / then exposed to $1.5 \mathrm{mg} \mathrm{Cu}-\mathrm{NPs} / \mathrm{l}$ of. Here histological abnormalities including hepatocytes necrosis (black arrow), a-nucleated hepatocytes (green arrow) and hepatocytes shrinkages (yellow arrow) can be seen. 


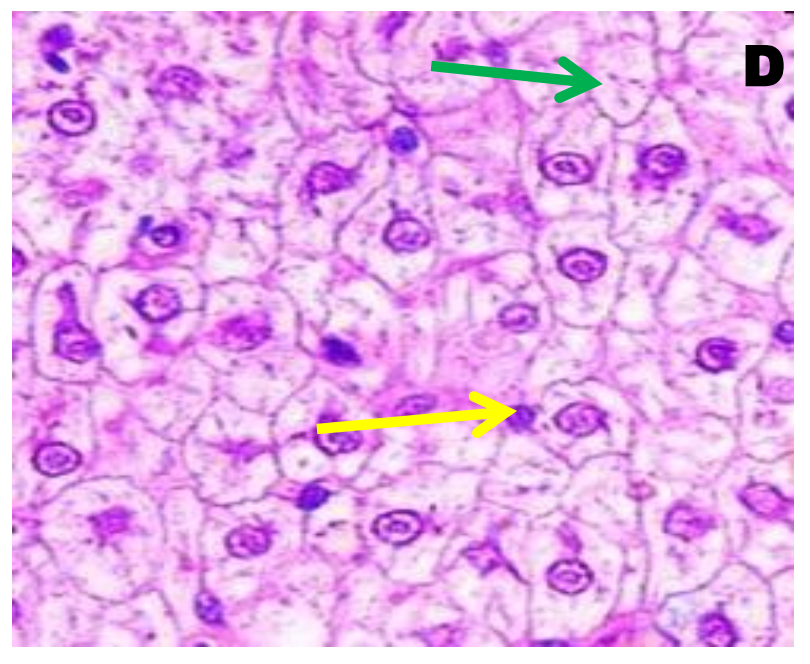

\section{Pre-CuNM2}

Figure 12 showing the pre-CuNM2 group which was pre-treated with $200 \mathrm{mg}$ MOSE / then exposed to $1.5 \mathrm{mg} \mathrm{Cu}-\mathrm{NPs} / \mathrm{l}$ of. Here histological abnormalities including a-nucleated hepatocytes (green arrow) and hepatocytes shrinkages (the yellow arrow) can be seen.



\section{Pre-CuNM3}

Figure 13 showing the pre-CuNM3 group which was pre-treated with $300 \mathrm{mg}$ MOSE / then exposed to $1.5 \mathrm{mg} \mathrm{Cu}-\mathrm{NPs} / \mathrm{l}$ of. Histological abnormalities including hepatocytes shrinkages (yellow arrow) are shown here. 


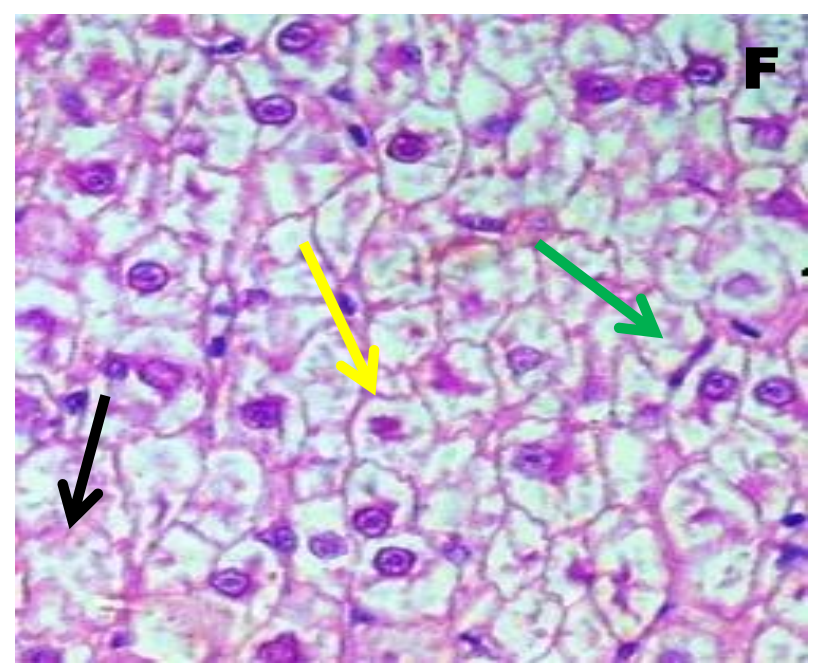

Post-CuNM1

Figure 14 showing the post-CuNM1 group which was pre-treated with $100 \mathrm{mg}$ MOSE $/ \mathrm{l}$ after exposing to $1.5 \mathrm{mg} \mathrm{Cu}-\mathrm{NPs} / \mathrm{l}$. Various histological abnormalities including hepatocytes necrosis (black arrow), a-nucleated hepatocytes (green arrow) and hepatocytes shrinkages (yellow arrow) are shown here.

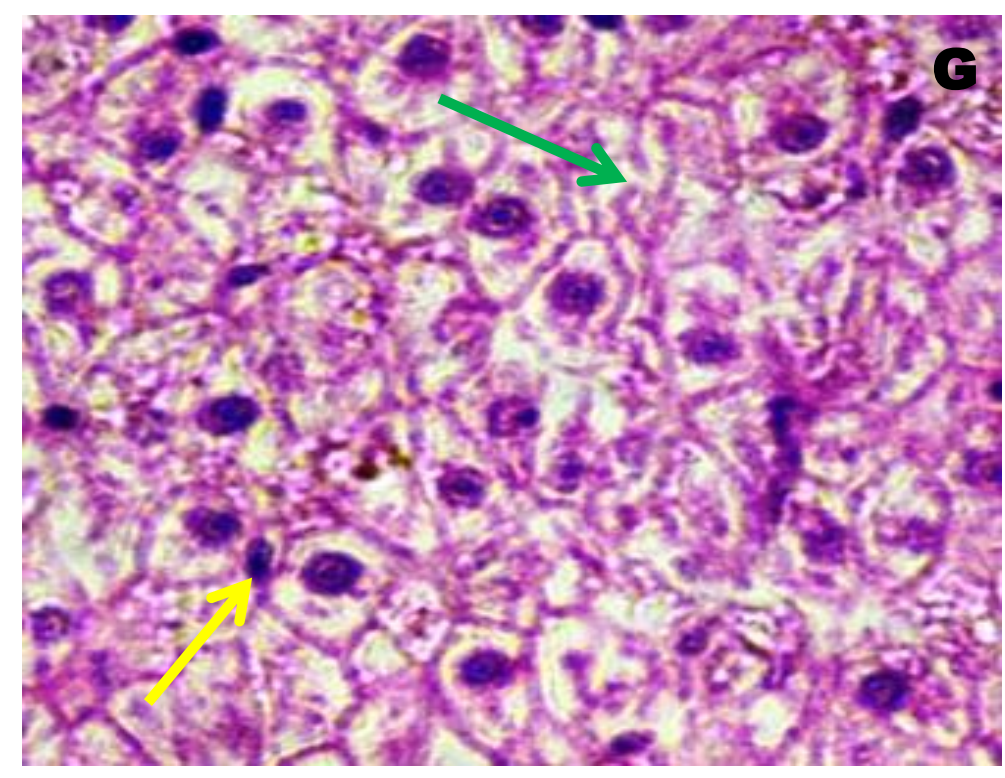

\section{Post-CuNM2}

Figure 15 showing the post-CuNM2 group which was pre-treated with $200 \mathrm{mg}$ MOSE $/ \mathrm{l}$ after exposing to $1.5 \mathrm{mg} \mathrm{Cu}-\mathrm{NPs} / \mathrm{l}$. Numerous histological abnormalities including a-nucleated hepatocytes (green arrow) and hepatocytes shrinkages (yellow arrow) are shown here. 


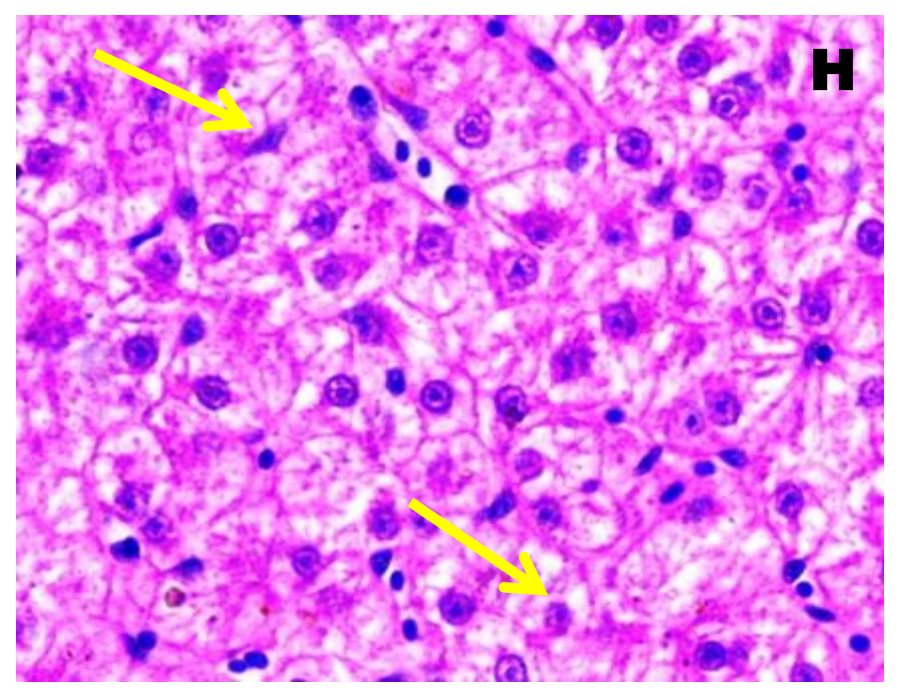

Post-CuNM3

Figure 16 showing the post-CuNM3 group which was pre-treated with $300 \mathrm{mg}$ MOSE $/ \mathrm{l}$ after exposing to $1.5 \mathrm{mg} \mathrm{Cu}-\mathrm{NPs} / \mathrm{l}$. Various histological abnormalities hepatocytes shrinkages (by the yellow arrow) are shown here. 
Table: 5 Histological alterations in liver of C. carpio exposed to different concentrations of M. olifera along with $1.5 \mathrm{mg}$ CuNPs /1

\begin{tabular}{|c|c|c|c|c|c|c|c|c|}
\hline Histological Alterations & $\mathrm{C}$ & $\mathrm{CuN}$ & Pre-CuNM1 & Pre-CuNM2 & Pre-CuNM3 & Post-CuNM1 & Post-CuNM2 & Post-CuNM3 \\
\hline Hepatocytes necrosis & - & +++ & ++ & + & $-/+$ & ++ & + & - \\
\hline A-nucleated hepatocytes & - & +++ & ++ & + & $-/+$ & ++ & + & $-/+$ \\
\hline hepatocytes shrinkage & - & +++ & ++ & + & $-/+$ & + & - & $-/+$ \\
\hline complete degeneration & - & +++ & ++ & + & - & - & - & - \\
\hline
\end{tabular}

(-) - no histological alterations (normal histological structure); (+/-) - mild histological alterations; (+) - moderate histological alterations; $(++)$ - severe histological alterations; $(+++)$ - very severe histological alterations in the liver. 


\section{Discussion}

The NPs have diverse applications in the fields of electronics, environmental decontamination and medicine. Due to substantial use of these NPs in the environment, it is critical to examine their potential toxic effects related to the human and even animal health [41]. Excessive production of ROS are attributed to the physico-chemical properties of NPs which may cause progression of many diseases due to the induction of oxidative stress [42].

M. oleifera is currently recognized as a potential antioxidant that may be effective against oxidative stress. This study has confirmed that that MOSE was able to significantly suppress the oxidative stress in the experimental fish. Santos et al. [43] who investigated the antioxidant activity of $M$. oleifera extracts from different parts of this plant demonstrated that $M$. oleifera extracts were the potential sources of antioxidants and so can be used as food sources. Das et al. [44] reported the ameliorative effect of $M$. oleifera leaf extract against elevated high fat diet that induced liver injury in mice. Moreover, significant increase in endogenous antioxidant parameters and lower lipid peroxidation were found in the liver of all $M$. oleifera leaf extract treated groups. Samkelisiwe et al. [45] investigated the antioxidant strength of $M$. oleifera leaves in different in vitro systems including its effects on the activity of SOD, CAT, LPO and GSH in goats supplemented with $M$. oleifera seed cake. The hepato-protective effect of aqueous $M$. oleifera leaf extract against radiation-induced oxidative stress in mice was assessed by Sinha et al. [46] by performing the immunoblotting and biochemical tests on the samples of mice liver. They reported that pretreatment of mice with $M$. oleifera leaf extract protected them against radiation-induced liver damage by reducing the oxidative damage. Sreelatha and Padma [47] reported the hydrogen peroxide-mediated DNA damage in human tumor KB cells and ability of $M$. oleifera leaf extracts to inhibit the oxidative damage. Sreelatha et al. [48] also reported the antioxidant properties of $M$. oleifera leaves against $\mathrm{CCl}_{4}$-induced oxidative damage in liver. They revealed that $\mathrm{CCl}_{4}$ treatment significantly decreased the activities of antioxidant enzymes but $M$. oleifera treatment had the ability to regain the control level of superoxide dismutase, catalase, glutathione peroxidase, glutathione reductase, glutathione S-transferase and glutathione contents.

Histological alterations could be used as a biomarker of stress induced by different pollutants in fish [49]. In the current study, Cu-NPs exposed groups when treated with MOSE for 28 days showed significant ameliorative effects. The gills are involved in many important functions in fish, such as respiration, osmoregulation and excretion. As the gills remain in close contact with the external environment they are assumed as the main target organ in fish for metal uptake [50]. An increase in the secretion of mucous, epithelial degeneration, lamellar fusion, lamellar hemorrhage and lamellar necrosis were observed in the current study in all the treatment groups, especially in group treated with $\mathrm{Cu}-\mathrm{NPs}$ at low dose of MOSE. It was also evident from this study that the gill abnormalities were significantly suppressed by MOSE in a dose dependent manner. It was the common observation among the treatments that along with the above stated abrasions, the mucus secretion was also increased especially at the low dose of MOSE which might be an indication of a protective response [49]. The mucous cells are efficient in seizing the toxic 
agents and thus may help in the prevention of the entrance of these agents into the gills [50]. The liver histology of experimental fish showed alterations in normal structure of liver but these abnormalities were only suppressed at the high dose of MOSE. It was most likely because of the antioxidant potential of MOSE against Cu-NPs induced oxidative stress. Furthermore, Fakurazi et al. [51] reported the protective effect of $M$. oleifera against acetaminophen induced toxicity in liver. The ameliorative capability of $M$. oleifera is due to its capability to induce phase II detoxification pathway by promoting GSH conjugation with toxic ions produced by CYP450 pathway [51]. The numerical changes in body weight and length of fish were observed in the current study when treated with MOSE which reflected the growth promoting effect of MOSE. The medicinal herbs and plants could serve as safer alternatives to growth promoters due to their suitability and preference, low cost of production, reduced risk of toxicity, minimum health hazards and environment friendliness [52-56].

\section{Conclusion}

It appeared that the MOSE can repair and significantly protect fish against deterioration caused by the tested dose of $\mathrm{Cu}-\mathrm{NP}$ as observed by the improvement in oxidative stress enzymes and histology. This positive response may be attributed to their potential bio-active components such as polyphenols, flavonoids and phenolic compounds. These compounds are known to present in MOSE which perhaps offered protection against oxidative damage caused by multiple known and unknown free radicals stimulated by $\mathrm{Cu}-\mathrm{NP}$.

\section{References}

[1] Yousefian M and Payam B 2012 Adv. Environ. Biol. 6(3) 1209-1215

[2] Argueta-Figueroa L, Morales-Luckie R A, Scougall-Vilchis R J and Olea-Mej'ia O F 2014 Prog. Nat Sci. Mat. Int; 24(4) 321-328

[3] Camacho-Flores B A, Martínez-Álvarez O, Arenas-Arrocena M C, Garcia-Contreras R, Argueta-Figueroa L, de la Fuente-Hernández J and Acosta-Torres L S 2017 J. Nanomat. Article ID 415238 1-10

[4] Wang T, Long X, Cheng Y, Liu Z and Jiangsu S Y 2014 Aquat. Toxicol. 152 96-104

[5] Ruparelia J P, Chatterjee A K, Duttagupta S P and Mukherji S 2008 Acta Biomaterialia 4(3) 707-16. doi:10.1016/j.actbio.2007.11.006

[6] Din M I and Rehan R 2017Anal Lett. 50(1) 50-62

[7] Wang T, Long X, Liu Z, Cheng Y and Yan S 2015 Fish shellfish immunol. 44(2) 674-82

[8] Griffitt R J, Weil R, Hyndman K A, Denslow N, Powers K, Taylor D and Barber D 2007 Environ. Sci. Technol. 41 8178-8186

[9] Jiang W, Kim B S, Rutka, J T and Chan W W 2008 Nat Nanotechnol. 3 145-150

[10] Magaye R and Zhao J 2012 Environ. Toxicol. Pharmacol. 34 644-650

[11] Ahamed M, Akhtar M J, Alhadlaq H and Alrokayan S 2015 Nanomedicine 10(15) 2365 -2377

[12] Sayes C M, Gobin A M, Ausman K D, Mendez J, West J L and Colvin V L 2005 Biomaterials 26 7587-7595 
[13] Brunet L, Lyon D Y, Hotze E M, Alvarez P J and Wiesner M R 2009 Environ. Sci. Technol. 43 4355-4360

[14] Shinohara N, Matsumoto T, Gamo M, Miyauchi A, Endo S and Yonezawa Y 2009 Environ. Sci. Technol. 43 948-953

[15] Baun A, Sorensen S N, Rasmussen R F, Hartmann N B and Koch C B 2008 Aquat. Toxicol. 86 379-87

[16] Brausch K A, Anderson T A, Smith P N and Maul J D 2010 Environ. Toxicol. Chem. 29 26002606

[17] Witasp E, Shvedova A A, Kagan V E and Fadeel B 2009 Inhal. Toxicol. 21 131-136

[18] Johnston H J, Semmler-Behnke M, Brown D M, Kreyling W, Tran L and Stone V 2009 Toxicol. Appl. Pahrmacol. 242 66-70

[19] Vieira A M S, Vieira M F, Silva G F, Araujo A A, Fagundes-Klein M R, Veit M T and Bergamasco R 2010 Water Air Soil Pollut. 206 273-281

[20] Compaoré W R, Nikièma P A, Bassolé H I N, Savadogo A, Mouecoucou J, Hounhouigan D J and Traoré S A Current Res. J. Biol. Sci. 3(1) 64-72

[21] Kusumaa I W, Arunga M E T and Kim S Y 2014 Food Sci. Human Well 3 191-196

[22] Hamid N H and Shirzad H 2013 J. Herbs Med. Pharmacol 2(2) 21-22

[23] Hassan S M, Al-Aqil A A and Attimarad M 2013 Adv. Med. Plant Res. 1(1) 24-28

[24] Fahey J W 2005 Part 1 Trees for Life J. 1(5) 1-6

[25] Anwar F and Rashid U 2007 Pak. J. Bot. 39(5) 1443-1453

[26] Josephine N, Kasolo, Gabriel S, Bimenya, Ojok L, Ochieng J and Ogwal-Okeng J W 2010 J. Med. Plants Res. 4(9) 753-757

[27] Kumar P S, Mishra D, Ghosh G and Panda C S 2010 Int. J. Phytomed. 2 210-216

[28] Kumar A, Naaz F, Kushwaha A, Chaudhary P and Srivastav P 2016 B. M. R. Phytomedicine 2(1) 1-17.

[29] Okechukwu P C U, Okwesili F C N, Parker E J, Abubakar B, Emmanuel C O and Christian E O 2013 Int. J. Life Sci. Biotechnol. Pharma. Res. 2(2) 66-71

[30] Velaga M K, Daughtry L K, Jones A C, Yallapragada P R, Rajanna S and Rajanna B 2014 J. Environ. Pathol. Toxicol. Oncol. 33(4) 323-337

[31] Compaoré W R, Nikièma P A, Bassolé H I N, Savadogo A, Mouecoucou J, Hounhouigan D J and Traoré S A 2011Current Res. J. Biol. Sci. 3(1) 64-72

[32] Aja P M, Ibiam U A, Uraku A J, Orji O U, Offor C E and Nwali B U 2013 Glob Adv. Res. J. Agri. Sci.2(5) 137-141

[33] Pakadei V, Cukrowska E and Chimuka L S 2013 A. J. Sci. 109 1-5

[34] Noureen A, Jabeen F, Tabish T A, Yaqub S, Ali M and Chaudhry A S 2018 Nanotechnology 29144003

[35] Khan R A, Khan M R and Sahreen S 2012 Expt. Toxicol. Pathol. 64(7-8) 725-731

[36] Jabeen F and Chaudhry A S Egypt J. Aquat. Biol. Fisheries 15 131-137

[37] Ohkawa H, Ohishi N and Yagi K 1979 Anal Biochem. 95 351-358 
[38] Aebi H 1974 Catalases Methods of enzymatic analysis ed H U Bergmeyer (New York: Academic) pp 673-84

[39] Sedalk J and Lindasy R H 1968 Anal Biochem. 25 192-205

[40] Bancroft J D and Stevens A 1999 Theory and practice of histological techniques hurchillLivingstone, London $4^{\text {th }}$ edn

[41]. Alarifi S, Ali D, Al-Doaiss A A, Ali B A, Ahmed M and Al-Khedhairy A A 2013 Int. J. Nanomedicine 8 3937-3943

[42] Christaki E 2012 Res. J. Biotechnol 7 109-12

[43] Joseph J A, Ayyappan U P T, Sasidharan S R, Mutyala S, Goudar K S and Agarwal A 2014 Pharmacognosy Res. 6(4) 320-325

[44] Santos A F, Argolo A C, Paiva P M and Coelho L C 2012 Phytother. Res. 26 1366-1370

[45] Das N, Sikder K, Ghosh S, Formenty B and Dey S 2012 Indian J. Expt. Biol. 50 404-412

[46] Samkelisiwe N H and Ngonidzashe A G M 2014 Turk. J. Fish 14 795-806

[47] Sinha M, Das D K, Datta S, Ghosh S and Dey S 2012 Indian J. Expt. Biol. 50 209-215

[48] Sreelatha S and Padma P R 2010 Forsch. Komp. Med. 17 189-194

[49] Sreelatha S, Jeyachitra A and Padma P R 2011 Food Chem. Toxicol. 1270-1275

[50] Sirimongkolvorakul S, Jiraungkoorskul W, Kosai P and Inwisai T 2015 J. Sci. Technol. 12(6) $565-571$

[51] Fakurazi S, Hairuszah I and Nanthini U 2008 Food Chem. Toxicol. 46 2611-2615

[52] Sharifi S D, Khorsandi S H, Khadem A A, Salehi A and Moslehi H 2013 Veterinarski Arhiv 83(1) $69-80$

[53] Sirimongkolvorakul S, Tansatit T, Preyavichyapugdee N, Kosai P, Jiraungkoorskul K and Jiraungkoorskul 2012 W. J. Med. Plants Res. 6 187-194

[54] Rogers G B, Hart C A, Mason J R, Hughes M, Walshaw M J and Bruce K D 2003 J. Clin. Microbiol. 41 3548-3558

[55] Mani F, Damasceno H C R, Novelli E L B, Martins E A M and Sforcin J M 2006 J. Ethnopharmacol. 105 95-98

[56] Talas Z S, Dundar S P, Gulhan M F, Orun I and Kakoolaki S 2012 Iranian J. Fisheries Sci. 11(2) 405- 414 